\title{
Tożsamość miejsca w krajobrazie kulturowym miasta Poznań - odbudowa Zamku Królewskiego Przemysła II
}

\author{
Paweł Szumigała, Piotr Urbański \\ Katedra Terenów Zieleni i Architektury Krajobrazu, Uniwersytet Przyrodniczy w Poznaniu
}

\begin{abstract}
Streszczenie: Praca omawia zagadnienia dotyczące odbudowy Zamku Królewskiego Przemysła II w Poznaniu - ważnej inwestycji w aspekcie tożsamości miejsca w krajobrazie kulturowym miasta. Podejmowane zagadnienia przedstawiono w kontekście uwarunkowań historycznych, przestrzenno-krajobrazowych i architektonicznych.
\end{abstract}

Słowa kluczowe: krajobraz kulturowy, Zamek Królewski Przemysła II, Poznań

\section{Wstęp}

Oprócz Gniezna, Poznań wraz z Krakowem i Warszawą należy do trzech miast, które kolejno pełniły w historii Polski funkcje stolicy a zamieszkujący w nich władcy posiadali swoje królewskie siedziby - zamki królewskie. Losy tych zamków były różne i tragiczne. Po okresach świetności następowały czasy zniszczeń i kolejnych odbudów. Pierwszym zamkiem, który po odzyskaniu niepodległości w latach 20. ubiegłego wieku został odbudowany wysiłkiem całego Narodu, jest Zamek Królewski na Wawelu. Również Zamek Królewski w Warszawie dzięki społeczeństwu doczekał się pieczołowitej odbudowy po II Wojnie Światowej w latach 70. i 80. XX wieku. Niestety Zamek Królewski Przemysła II w Poznaniu, wielokrotnie niszczony i odbudowywany nie zawsze z należytą godnością, po roku 1945 pozostawał przez wiele lat w zapomnieniu. W tym okresie dokonano tylko skromnej częściowej rekonstrukcji obiektów przy murze północnym - „Budynek Raczyńskiego”. Nie odbudowano najbardziej charakterystycznego obiektu - wieży zamkowej i obiektu z charakterystycznymi szczytami. Siedziba Przemysła II wzniesiona w XIII wieku na Wzgórzu Zamkowym w Poznaniu, zwanym również Górą Przemysława, Górą Przemysła lub Górą Zamkową, jest symbolem jednoczącej się narodowości i kolebką Państwa Polskiego. Oprócz pięknego renesansowego Ratusza Poznańskiego, Fary Poznańskiej i Bazyliki Archikatedralnej na Ostrowiu Tumskim, Zamek Królewski Przemysła II należy do najważniejszych obiektów śródmieścia Poznania, które stanowią zasadnicze elementy krajobrazu kulturowego miasta. Siedziba Przemysła II, to istota tożsamości miejsca historycznej stolicy Polski. Dopiero początek XXI wieku przyniósł nadzieję na odbudowę zamku. W kwietniu 2002 roku powstał Komitet Odbudowy Zamku Królewskiego w Poznaniu', który ze względów prawnych i idących za tym większych możliwości działania, został przekształcony w Stowarzyszenie - Komitet Odbudowy Zamku Królewskiego w Poznaniu. Stowarzyszenie zostało zarejestrowane w grudniu 2002 roku. Założenia realizacyjne Stowarzyszenia przewidywały rozpoczęcie budowy na rok 2005. Zakończenie budowy i otwarcie Zamku, ze względów na szereg pojawiających się trudności nastąpiło dopiero w roku 2016 w 721 rocznicę koronacji

1 fragment wypowiedzi wojewody poznańskiego i senatora V kadencji Włodzimierza Łęckiego w wywiadzie przeprowadzonym przez Macieja Kabsha opublikowana na stronie e-poznan.pl dnia 24.09.2010 roku ... Zostałem namówiony, by wejść w skład Komitetu Odbudowy Zamku Królewskiego w Poznaniu i zostałem wybrany prezesem. Komitet powstał w 2002 r. z inicjatywy Towarzystwa Opieki nad Zabytkami i przy poparciu osiemnastu organizacji zwiazanych z kultura, zabytkami i turystyka, m.in. SARP, PTTK $i$ kilku innych. W pierwszych latach zebraliśmy pewne materiały. Później zorganizowaliśmy zbiórkę pieniędzy. Zebraliśmy przez 8 lat 1,2 miliona złotych. Zebrane środki pozwolity nam na ogłoszenie ogólnopolskiego, otwartego konkursu, w którym wzięło udział 21 zespołów. Jury pod przewodnictwem obecnego architekta miasta pana Andrzeja Nowaka rozstrzygnęto konkurs na korzyść pracowni „Arcus”, gdzie architektem był pan Witold Milewski.... Źródło: https:// epoznan.pl/news-news-21049-Pan_Lecki_i_jego_zamek (data dostępu 27 listopada 2017) 
Przemysła II. Jednym z niezwykle istotnych problemów, który pojawił się na drodze do szybkiej realizacji było zorganizowanie funduszy oraz wybór wizji - koncepcji projektowej. Ze względu na niezwykle skąpe przekazy historyczne na temat formy siedziby Przemysła II i kolejnych etapów rozwoju zabudowań zamkowych, należało ustalić ramy możliwych interpretacji formy architektonicznej.

\section{Cel, materiał i metody}

Celem artykułu jest prezentacja uwarunkowań historycznych, walorów i związków przestrzennych, krajobrazowych i kulturowych w tworzeniu tożsamości miejsca na przykładzie odbudowy Zamku Królewskiego w Poznaniu. W badaniach zastosowano metodę kwerendy historycznej i studia przypadku. Obszar badań, to rozpoznanie procesu odbudowy obiektu historycznego w krajobrazie kulturowym miasta.

\section{Wyniki}

\section{Rys historyczny}

Czas powstania Zamku Królewskiego w Poznaniu, to XIII wiek. Wznoszenie rezydencji obronnych w tych czasach było wyłącznym przywilejem panujących władców a Zamek w Poznaniu należy do ufortyfikowanych rezydencji królów polskich. Jest on najstarszym tego typu zabytkiem, gdyż wcześniejsze siedziby królewskie - grody - trudno nazwać zamkami. Pierwotna forma zamku pozostaje nadal w sferze hipotez, gdyż odkryte, zachowane do dzisiaj pierwotne elementy nie pozwalają na dokonanie analizy porównawczej z innymi powstającymi w tym okresie zamkami w Polsce [Kajzer i in. 2001, Chorowska 2003]. Zamek w Poznaniu zliczany jest do zamków wyżynnych i jednocześnie miejskich, co wynika z nierozerwalnego związku tej budowli z fortyfikacjami miejskimi. Budowę nowej siedziby królewskiej na Wzgórzu Zamkowym rozpoczęli w połowie XIII wieku Przymysław I i Bolesław Kaliski, którzy zrezygnowali z grodu położonego na Ostrowiu Tumskim w pobliżu katedry. Przemysław II, syn Przemysła I i Elżbiety, córki Henryka Pobożnego, zakończył budowę zamku najprawdopodobniej w kształcie, zachowanych do dzisiaj fragmentów najstarszych fundamentów. W tych czasach istotnym argumentem obronnym oraz politycznym były rozmiary i wyraz przestrzenny budowli królewskiej. Siedziba Przemysła II odbiega w tym zakresie od wzorców sobie współczesnych, gdzie wieże obronne wpisane były w obrysy murów obronnych. W przypadku Zamku w Poznaniu wieża obronna, która również pełniła funkcje mieszkalne usytuowana została poza murem obronnym i posiadła znaczne wymiary rzutu $11 \times 11 \mathrm{~m}$, a grubość jej ścian wynosiła $3 \mathrm{~m}$ [Linette 1981]. Takie usytuowanie wieży umożliwiło prowadzenie ostrzału w trzech kierunkach. Ryc. 1 a.
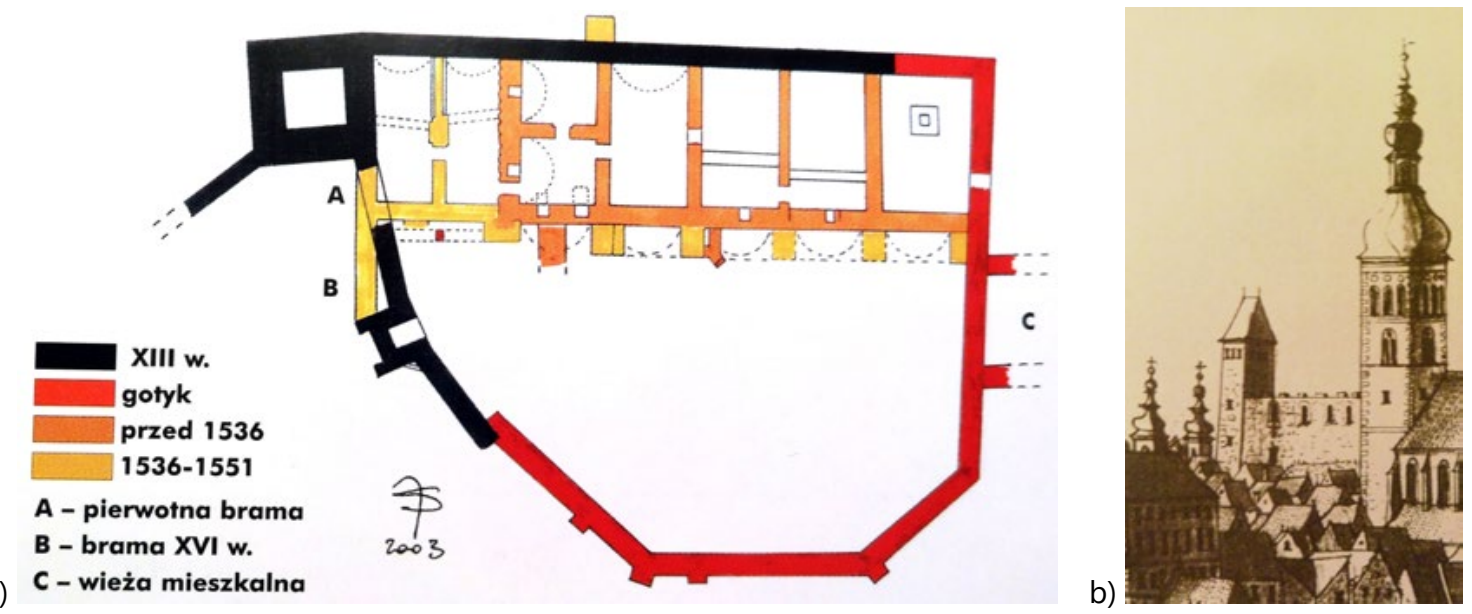

Ryc. 1. A - Plan fundamentów i murów przyziemia Zamku Królewskiego w Poznaniu wg prof. Jana Skuratowicza, B - Fragment widoku Poznania F. Wernera z 1734 r. Źródło: Łęcki i in. 2004, Zamek Królewski w Poznaniu, działania na rzecz restytucji, Poznań. 
Zaskakującym jest również rozplanowanie murów obronnych na wierzchołku niedużego Wzgórza Zamkowego, które nie przebiegały zgodnie z owalnym ukształtowaniem terenu. Przejawem tego są proste, o niespotykanej długości na ziemiach polskich w tych czasach, odcinki murów do których, najprawdopodobniej - zgodnie z zamierzeniami władcy, miały przylegać dużych rozmiarów skrzydła zamkowe. Długość zachodniego odcinka muru wynosiła $64 \mathrm{~m}$, co porównywalne było jedynie do palatium o wymiarach 61,5×16,15 m, wzniesionego w Legnicy przez Henryka Brodatego, pradziada Przemysła II [Dolczewski 1996]. Wymiary budowli miały dla króla wymowę symboliczną. O ambicjach i pozycji władcy poznańskiego świadczy również to, że wieżę, część murów obronnych i zabudowań zamkowych wybudowano z cegły w wątku wendyjskim, najstarszym układzie stosowanym na ziemiach polskich. Dopiero w później realizowanych częściach i kolejnych przebudowach zamku pojawia się wątek gotycki. W ówczesnych czasach cegła była materiałem nowoczesnym i jej zastosowanie świadczyło o wyjątkowym prestiżu inwestora. Natomiast niewątpliwym i najważniejszym symbolem panowania Przemysła II była wysoka wieża zamkowa, która górowała nad miastem pełniąc rolę dominanty przestrzenno-krajobrazowej a dla mieszkańców była realnym i widocznym (z wielu kierunków) przejawem tożsamości miejsca - władzy i miasta. W chwili koronacji Przemysł II był najpotężniejszym z polskich książąt dzielnicowych i poza Wielkopolską skupiał władzę nad Księstwem Gdańskim. Fakt ten miał doniosłe znaczenie polityczne, stwarzał on podstawy do zjednoczenia ziem polskich i restytucji królestwa. Sam obrzęd koronacji był zaś wydarzeniem doniosłym, gdyż od poprzedniej koronacji Bolesława Śmiałego upłynęło 219 lat i przez ten czas korona królewska spoczywała w skarbcu na Wawelu. Koronacja Przemysła II dokonana została w katedrze gnieźnieńskiej 26 czerwca 1295 roku przez arcybiskupa Jakuba Świnkę. Po śmierci Henryka Probusa (1290) Przemysł II stał się na krótko również królem Krakowa, lecz wkrótce musiał scedować władzę nad tą dzielnicą na rzecz Wacława II. Jak podają przekazy historyczne, Przemysł II swoje pochodzenie wywodził z trzech dynastii cesarskich i większości europejskich dynastii królewskich. Jego prababką była św. Jadwiga z rodu von Andechs. Ród ten wywodził się od Arnulfa, ostatniego cesarza karolińskiego. Niestety rządy króla Przemysła II nie trwały długo, został on zamordowany w niespełna rok po koronacji - w dniu 2 lutego 1296 roku w Rogoźnie w wyniku spisku Brandenrburczyków, Nałęczów i Zaręmbów. Polityka terytorialna i obronna Przemysła Il, który dążył do zjednoczenia, wzmocnienia ziem polskich i skutecznej obrony przed najazdami Brandenburczyków, przeszkadzała nie tylko zachodniemu sąsiadowi lecz również polskim rodom, które wzięły udział w spisku i zamordowaniu króla. Po śmierci Przemysła Il dopiero syn Łokietka, Kazimierz kontynuował budowę zamku na Górze Zamkowej gdy został namiestnikiem Wielkopolski w 1331 roku. Najprawdopodobniej już jako król wzniósł północną wieżę mieszkalną o wymiarach $13 \times 15$ m ze studnią oraz piętrowy budynek przy zachodnim murze. Zamek Królewski w Poznaniu był w kolejnych latach świadkiem wielu ważnych i doniosłych ceremonii oraz spotkań. Biorąc pod uwagę potrzeby reprezentacyjne siedziby królewskiej, został rozbudowany na tyle ile pozwalały warunki terenowe. Zamek posiadał salę, sklepioną komnatę i kaplicę. Tak jak planował pierwotnie Przemysł II wzdłuż północnego muru powstał szereg pomieszczeń. Na zamku w Poznaniu regularnie bywał Władysław Jagiełło (co najmniej 36 razy) i dwukrotnie z żoną Jadwigą. Zamek w tym czasie musiał pomieścić dwa dwory króla i królowej. W tym czasie król Władysław Jagiełło ufundował najstarszą w Polsce monstrancję dla kościoła Bożego Ciała w Poznaniu. W roku 1475 gościł Kazimierz Jagiellończyk, który żegnał swą córkę wydaną za mąż za księcia Bawarii Jerzego Wittelsbacha z Landshut [Łukaszewicz 1996]. Z przekazów historycznych bryła zamku składała się wówczas z prostopadłościennego dwukondygnacyjnego skrzydła mieszkalnego z czterema szczytami, za którymi znajdowały się cztery dwuspadowe dachy, Ryc. 1B. Od strony dziedzińca najprawdopodobniej istniały krużganki dostawione do ściany a od strony zachodnio-południowej przylegała wieża z wysokim dachem namiotowym o dwóch dominujących połaciach z dwoma sterczynami na poziomej kalenicy. Kolejne wieki przynosiły siedzibie królewskiej w Poznaniu na przemian okresy prosperity i upadku a Zamek był świadkiem wielu wydarzeń historycznych. W 1493 r. na Zamku w Poznaniu wielki mistrz krzyżacki Hans von Tieffen złożył królowi Polski hołd lenny. W kolejnych wiekach Zamek był wielokrotnie niszczony i odbudowywany. Do najważniejszych z tego okresu należy zaliczyć: odbudowę prowadzoną w XVI wieku przez Andrzeja Górkę i przebudowę z wieku XVIII wykonaną przez E. Raczyńskiego. W wyniku tej ostatniej został zlikwidowany czwarty skrajny szczyt i ten fragment zabudowań został włączony do obiektu nazwanego „Budynkiem Raczyńskiego" lub "Skrzydłem Raczyńskiego", który posiadał uproszczoną dwukondygnacyjną formę dworu polskiego z polskim dachem łamanym i małym szczytem. Liczne zniszczenia i przebudowy Zamku zmieniły jego pierwotną bryłę, jednak w świadomości mieszkańców zawsze wzbudzał poczucie tożsamości narodowej i pozostawał symbolem początków państwowości polskiej i władzy królewskiej. 


\section{Uwarunkowania przestrzenno-krajobrazowe}

Zamek powstał na niewielkim wzgórzu w skrzyżowania dolin Warty i Bogdanki. Rzeczka Bogdanka obecnie płynie w kanale pod Placem Wielkopolskim, który przylega do Zamku od strony północnej. U podnóża Wzgórza Zamkowego w czasach Przemysła II przepływała najprawdopodobniej struga - odnoga Warty zwana Notecią. Obecnie Wzgórze Zamkowe znajduje się na granicy dwóch odmiennych struktur urbanistycznych, Ryc. 2. Od strony wschodniej graniczy ze Starym Miastem, którego układ urbanistyczny powstawał w średniowieczu a od zachodniej z obszarem zabudowy XVIII wiecznej, z czasów rewolucji przemysłowej i współczesnej. Istotnymi elementami struktur otaczających obecnie Zamek są przestrzenie publiczne - place i ulice, które umożliwiają pieszym krótkie i dalekie ekspozycje - widoki na Zamek: od wschodu Stary Rynek z Ratuszem, ulice: Karmelicka, Podgórna i Zamkowa, od północy Plac Wielkopolski, ulice: Działowa i 23 lutego, od zachodu Plac Wolności i Aleje Marcinkowskiego, od południa skwer przed Kościołem O.O Karmelitów, ulice: Ludgardy, Sieroca i Paderewskiego.

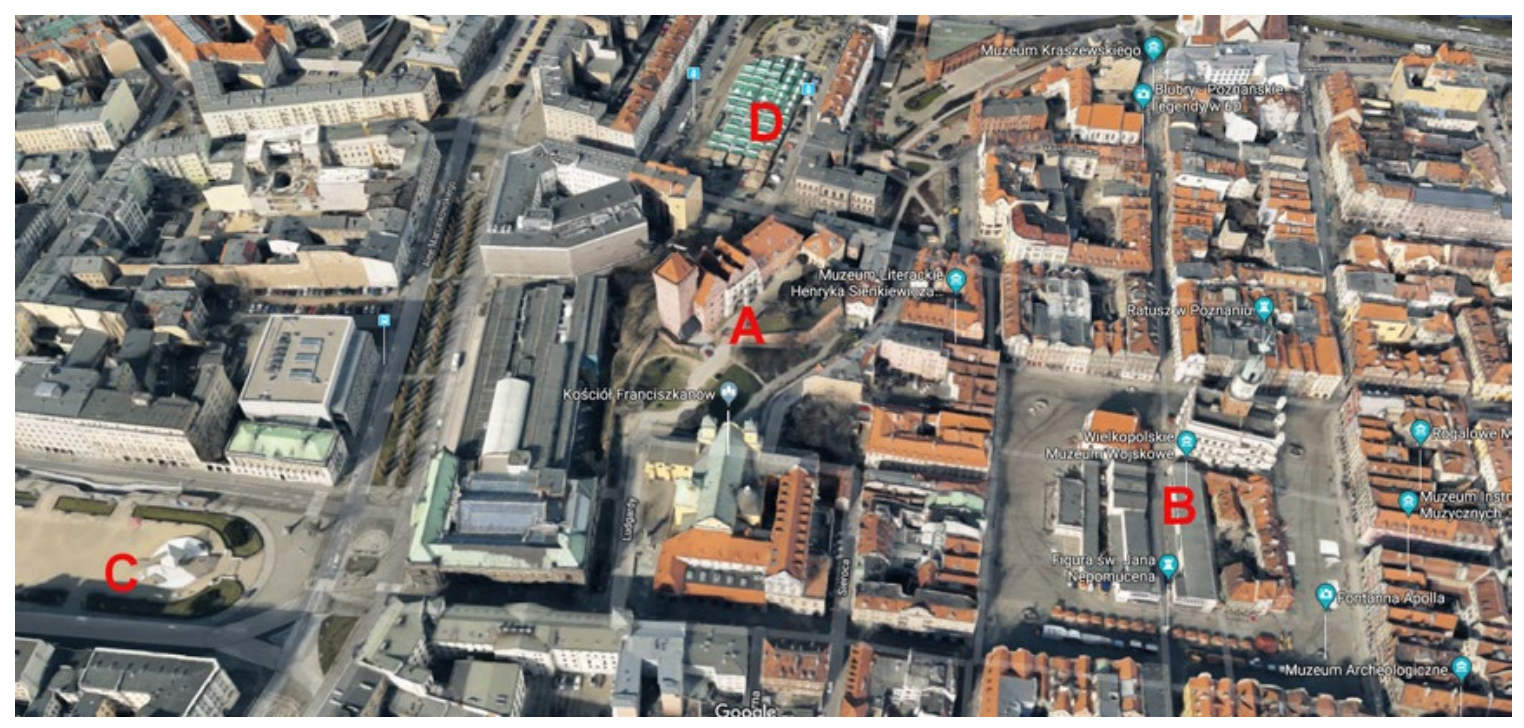

Ryc. 2. Zamek Królewski w Poznaniu po odbudowie z 2013 roku - widok z góry: A- Zamek Królewski, B - Stary Rynek z Ratuszem, C - Plac Wolności, D - Plac Wielkopolski. Źródło: https://www.google.pl/maps/place/Pozna\%C5\%84/@52.4060 392,16.9312135,386a,35y,39.35t/data=!3m1!1e3!4m5!3m4!1s0x470444d2ece10ab7:0xa4ea31980334bfd1!8m2!3d52.40637 4!4d16.9251681?hl=pl, (data dostępu 27 listopada 2017 rok).

W tym rejonie występują głównie kierunki widokowe na Zamek w postaci otwarć architektonicznych (wykadrowanych widoków) z ulic i przerw pomiędzy budynkami oraz widoki na wieże i szczyty ponad otaczającą Zamek zabudową, odczytywane jako subdominata ${ }^{2}$ przestrzenna, Ryc. 3. Widoki panoramiczne występują w ekspozycjach z większej odległości np. z rejonu Ostrowa Tumskiego, drugiego brzegu rzeki Warty i tarasów dzielnicy Rataje. 

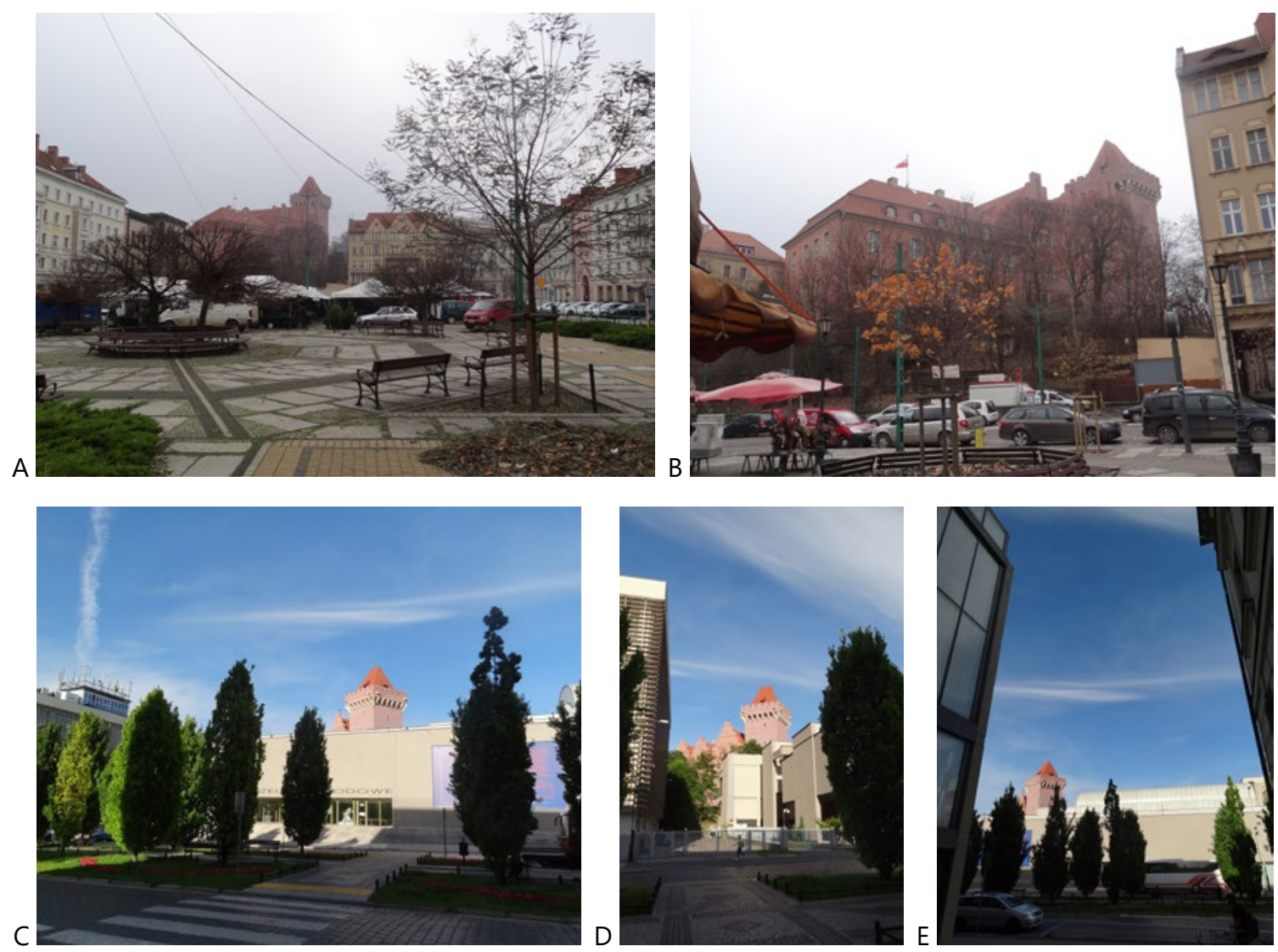

Ryc. 3. Zamek Królewski w Poznaniu po odbudowie: A, B - ekspozycje widokowe bryły zamku z Placu Wielkopolskiego, C, D, E - Wieża zamkowa widziana z Alei Marcinkowskiego jako subdominanta w otwarciach architektoniczno-krajobrazowych. Źródło: P. Szumigała, czerwiec/wrzesień 2017.
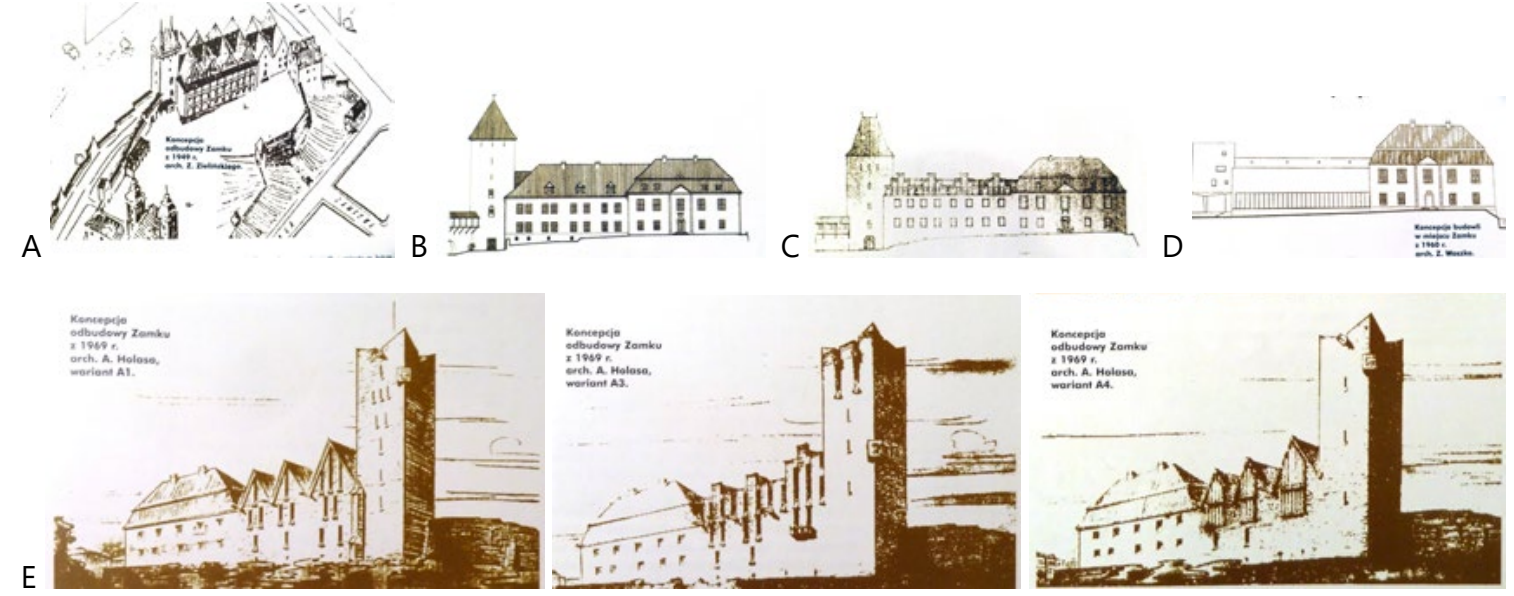

Ryc. 4. A - koncepcja z 1949 arch. Z. Zielińskiego, B - koncepcja z 1949 arch. F. Rychlickiego, C - koncepcja z 1950 arch. F. Rychlickiego, D - koncepcja z 1950 arch. F. Rychlickiego i arch. S. Podgórskiego, E - trzy koncepcje z 1969 arch. A. Holasa. Źródło: Łęcki i in. 2004, Zamek Królewski w Poznaniu, działania na rzecz restytucji, Poznań. 


\section{Odbudowa Zamku po 1945 roku}

Zniszczenia zabytkowego Starego Miasta po 1945 roku sięgały ponad 60 \% zabudowy. Z zabudowań zamkowych pozostało kilka ścian „Budynku Raczyńskiego” i spalony budynek tzw. „Kuchni Królewskiej”. Taki stan rzeczy spowodował, że przystąpiono do odbudowy i działań rekonstrukcyjnych na szeroką skalę. Niestety brak przekazów o formie Zamku z drugiej połowy wieku XIII przesądził o tym, że podjęto decyzję o odbudowie według dostępnych informacji z okresu po 1536 roku, tj. z czasów odbudowy Zamku przez starostę wielkopolskiego Andrzeja Górkę. W roku 1949 powstał projekt rekonstrukcji Zamku w formach szesnastowiecznych z krużgankami wykonany przez arch. Z. Zielińskiego, który przygotował również projekt i program odbudowy Starego Miasta w Poznaniu. W tym samym roku przygotowana została przez arch. F. Rychlickiego druga koncepcja utrzymana w konwencji z czasów odbudowy prowadzonej przez Andrzeja Górkę. W roku 1950 arch. F. Rychlicki wykonał jeszcze dwie koncepcje samodzielnie i we współpracy z arch. S. Podgórskim. Ryc. 4. Jednakże żadna z tych koncepcji nie doczekała się realizacji. W tym czasie odbudowano i wyremontowane zostały jedynie „Budynek Raczyńskiego" i spalony budynek „Kuchni Królewskiej”, który pełnił funkcje mieszkalne. W roku 1965 Stowarzyszenie Architektów Polskich (SARP) przeprowadziło ogólnopolski konkurs na rozbudowę Muzeum Narodowego i zabudowy na Wzgórzu Zamkowym. Spodziewano sie wówczas, że konkurs przyniesie szereg nowych rozwiązań, również w zakresie odbudowy Zamku. Pomimo znacznej liczby prac - 31, które wpłynęły na konkurs nie uzyskano w tym zakresie wyczerpującej i odpowiedniej odpowiedzi. W roku 1969 podjęto kolejną próbę projektową uzupełnienia zabudowy zamkowej. Prace powierzono arch. A. Holasowi, który przygotował trzy propozycje. Koncepcje te nawiązywały do przekazów ikonograficznych, według których brakujący sąsiadujący ze "Skrzydłem Raczyńskiego" budynek miał formę zwieńczoną trzema szczytami i zakończony był wysoką przylegającą od niego wieżą o stylizacji gotyckiej. Niestety rozbudowa Muzeum Narodowego w Poznaniu (odbudowa Zamku leżała wówczas również w gestii Dyrekcji Muzeum Narodowego) odsunęła sprawę odbudowy Zamku na kolejne lata aż do roku 1994. Wtedy to, Fundacja Ochrony Zabytków Wielkopolski wpisała do swych zadań statutowych odbudowę Zamku i zorganizowała w tymże roku publiczną dyskusję na ten temat. W sprawę odbudowy Zamku zaangażowały się trzy organizacje: Towarzystwo Miłośników Miasta Poznania, Towarzystwo Opieki nad Zabytkami Oddział w Poznaniu oraz Poznański Oddział Towarzystwa Urbanistów Polskich, które zorganizowały w 2001 roku konferencję „Rola Zamku Królewskiego w stołecznym staromiejskim zespole". Konferencja skupiła czternaście stowarzyszeń, kilkunastu gości i zakończyła się powołaniem Komitetu Odbudowy Zamku Królewskiego w Poznaniu. W międzyczasie w latach 1999, 2000 i 2002 zostały podjęte kolejne próby projektowe prezentujące różne nurty od: zabudowy współczesnej i modernistycznej (zespół architektów z Hamburga), poprzez swobodną interpretację przekazów ikonograficznych (zespół pod kierunkiem arch. R. Barełkowskiego) aż po rozwiązania o wyrazie konserwatorskim ściśle nawiązujące do materiałów historycznych (autorstwa prof. J. Skuratowicza i pracowni „Klimaszewska i Biedak”), Ryc. 5. Ostatecznie, Komitet Odbudowy Zamku Królewskiego w Poznaniu po doświadczeniach projektowych ostatnich kilkudziesięcioleci zdecydował o rozpisaniu w roku 2003 nowego, otwartego, ogólnopolskiego konkursu, na który wpłynęły 22 prace ${ }^{3}$. Komisja konkursowa ${ }^{4}$ określiła wytyczne projektowe, których spełnienie miało na celu wyłonienie pracy najbardziej wiarygodnej i najbardziej zbliżonej do pierwowzoru, którego obraz istniał jedynie w szczątkowych przekazach ikonograficznych i częściowo zachowanych fundamentach oraz fragmentach ścian. Odbudowany „Budynek Raczyńskiego" uznano jako element stały, który należy honorować w rozwiązaniach konkursowych. Najbardziej istotnymi i fundamentalnymi ustaleniami było uznanie, że niemożliwym jest: odbudowanie Zamku w dowolnej formie współczesnej oraz rekonstrukcja obiektu, ze względu na brak dokładnych materiałów ikonograficznych.

3 1. Studio Archidea, 2. Biuro Architektoniczne Maciej Soczyński, 3. architekci Tomasz Gamzdyk i Wojciech Kawęczyński, 4. arch. Maciej Hadrych, 5. Pracownia Architektoniczna Forrma, 6. arch. Henryk Pielichowski, 7. Pracownia Architektoniczna Arcus, 8. Atrium A.S.A 9. Arcada, 10. arch. Kazimierz Socha, 11. Pro-Bud Poznań, 12. Archidea Joanna i Maciej Petz, 13. Biuro Inżynieryjno-Techniczne Karo, 14. Zespół Architektoniczny arch. arch. Tadeusz Biedak-Piotr Bukowy-lzabela Klimaszewska, 15. Architektoniczne Biuro Projektowe Stefan Wojciechowski, 16. Autorska Pracownia Macieja Małachowicza, 17. Autorska Pracownia Architektoniczna Paweł Szumigała, 18. Ac-Studio Jacek Sołgała-Jarosław Romański, 19. Vowie Studio, 20. Armageddon-Biuro Projektowe, 21. Arpa - Architektoniczna Pracownia Autorska Jerzy Gurawski, 22. Projektplan - Przybylski Architektura i Urbanistyka.

4 Przewodniczący Komisji: Andrzej J. Nowak - Architekt Wojewódzki, Sekretarz Komisji: Jacek Cenkiel - prawnik, Członkowie Komisji: Zygmunt Dolczewski - historyk sztuki, Tadeusz Gałecki - architekt, Jerzy Gładysiak - inżynier, Aleksander Grygorowicz - architekt, Wojciech Jędraszak - inżynier, Andrzej Kubasiewicz - inżynier, Andrzej Kaszubkiewicz - historyk, Henryk Kondziela - historyk sztuki, Andrzej J. Kowalski - inżynier, Marian Krzysztofiak - inżynier, Janusz Pazder - historyk sztuki, Tadeusz Pełeszuk - Architekt Miejski, Jan Skuratowicz - historyk sztuki, Maria Strzałko - Miejski Konserwator Zabytków, historyk sztuki, Przemysław Wojciechowski - architekt. 

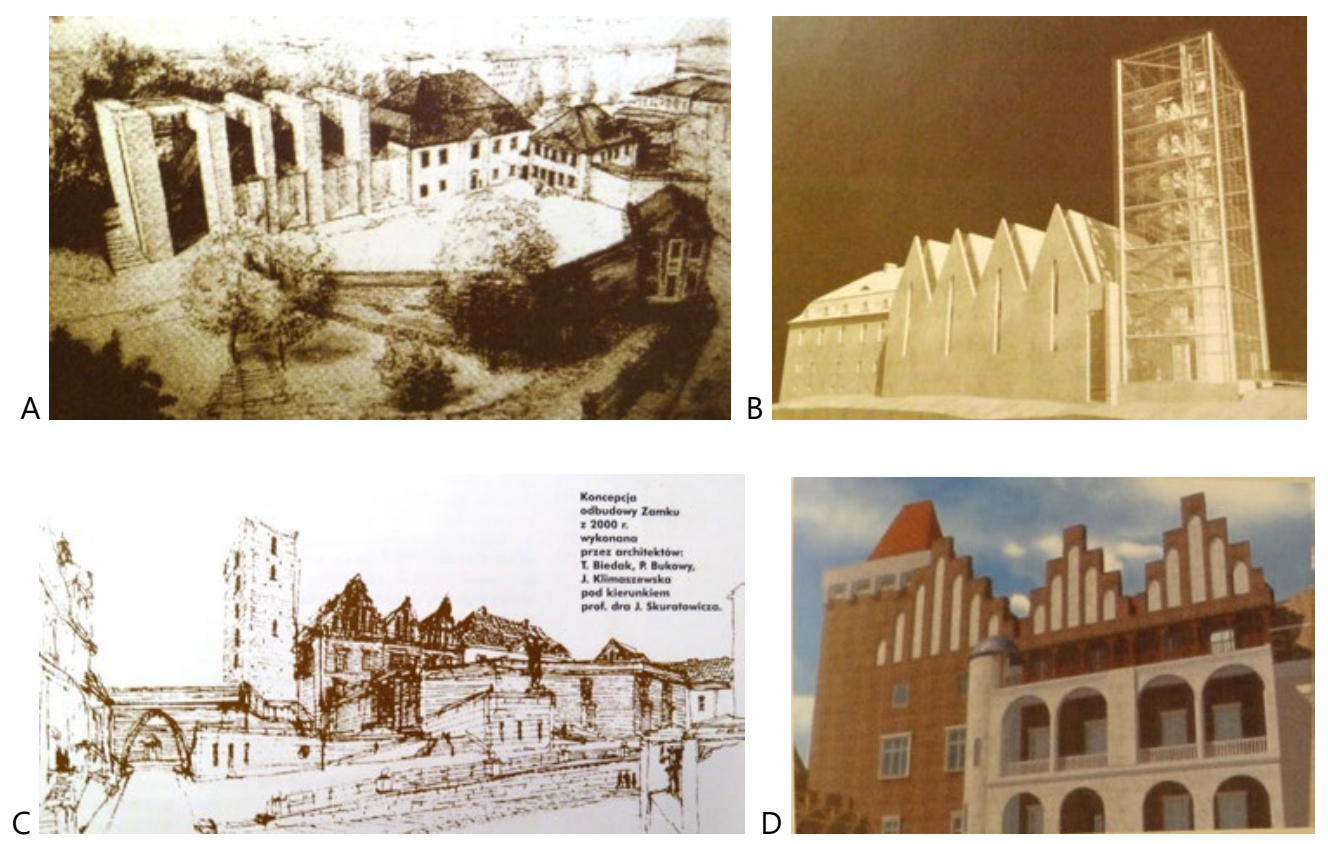

Ryc. 5. A - koncepcja z 1999 architektów z Hamburga, B - koncepcja z 2002 arch. R. Barełkowskiego, C - koncepcja z 2000 pracowni Klimaszewska i Biedak pod kier. prof. J. Skuratowicza, D - zwycięska praca arch. Witolda Milewskiego z zespołem. Źródło: Łęcki i in. 2004, Zamek Królewski w Poznaniu, działania na rzecz restytucji, Poznań.

W zakresie ustaleń szczegółowych najważniejszym był: nakaz odbudowy wieży na rzucie odkrytych zachowanych fundamentów i murów oraz zabudowa zamkowa pomiędzy "Budynkiem Raczyńskiego” a wieżą, która powinna być wzniesiona na rzucie istniejących starych murów, jako budynek trzykondygnacyjny zwieńczony trzema szczytami. Szczyt przy wieży miał być szerszy a dach pokryty dachówką w formie trzech poprzecznych, dwuspadowych osobnych dachów. Taki stan rzeczy wywołał jednak wśród jurorów spór ideowy dotyczący zasad, według których powinno się dochodzić do rozwiązań architektoniczno-przestrzennych nieistniejących elementów zagospodarowania i zabudowań zamkowych. Podobne dylematy ujawniły się również w pracach konkursowych, gdzie wyraźnie zarysowały się dwa nurty, które podzieliły uczestników na dwie równe części: połowa uczestników konkursu operowała formami historyzującymi, pozostali prezentowali wyraźnie rozwiązania nowoczesne [Szumigała 2004]. Ostatecznie komisja konkursowa po dwuetapowym głosowaniu wyłoniła zwycięską pracę, która stała się podstawą do wykonania projektu realizacyjnego Ryc. 5D. Jednakże cały proces inwestycyjny i prace budowlane trwały kilkanaście lat, gdyż co jakiś czas pojawiały się kolejne przeszkody, głównie techniczne i finansowe. Ostateczna zrealizowana wersja odbudowy Zamku zakończona w roku 2016 częściowo odbiega od zwycięskiego projektu. Najbardziej spornym i wywołującym obecnie odmienne zdanie wśród mieszkańców i architektów jest zwieńczenie wieży dużym krenelażem, tym bardziej, że ten właśnie fragment jest wizytówką Zamku i widoczny jest z wielu miejsc miasta, zarówno w widokach lokalnych jak i panoramach miasta. Obecnie w Zamku mieści się między innymi Muzeum Sztuk Użytkowych a na wieży zamkowej znajduje się taras widokowy, z którego można podziwiać pełną panoramę Poznania.

Tak kończy się opowieść o trudnych czasach egzystencji i dokończonej po wielu latach odbudowy Zamku Królewskiego w Poznaniu. W końcu Poznań doczekał się realizacji tak ważnego przestrzennie i kulturowo elementu w jego krajobrazie. Pomimo różnych opinii dotyczących zrealizowanego rozwiązania architektonicznego Zamek Królewski w Poznaniu stanowi najważniejszy fizyczny obiekt tożsamości Wielkopolan. W czasach Kazimierza III Wielkiego (gdy powstawał) był największym murowanym obiektem świeckim na Ziemiach Polskich. 


\section{Podsumowanie}

Długa i wyboista droga, jaka ostatecznie doprowadziła do zakończenia odbudowy Zamku Królewskiego w Poznaniu była udziałem wielu zaangażowanych w tę sprawę Wielkopolan. Poznań jako najstarsza stolica Polski zasługuje na to aby górował nad nim Zamek Królewski. Jest on wyrazem dążenia wielu pokoleń do samostanowienia i niepodległości, tak jak to czynił Przemysł II, którego imię kojarzy się nierozerwalnie z siedzibą królewską w Poznaniu. Historia dziejów Zamku w Poznaniu, zarówno tych dawnych jak i współczesnych jest również odzwierciedleniem historii Wielkopolan, stąd tak duże przywiązanie wśród mieszkańców Poznania i Wielkopolski do tego symbolu państwowości Polskiej i tożsamości narodowej oraz tożsamości miejsca jakim jest miasto Poznań. Zamek Królewski w Poznaniu pojawił się w krajobrazie kulturowym miasta jako najważniejszy i przez wiele lat brakujący jego element.

\section{Wnioski}

1. Odbudowa Zamku w Poznaniu to przykład działań oddolnych, stowarzyszeń i grup zaangażowanych w te sprawę Wielkopolan.

2. Brak materiałów historycznych przy odbudowie tak wiekowego obiektu nie przekreślił możliwości jego odbudowy, co stanowi również inspirację i tajemnicę jego historii.

3. Interpretacja i ocena estetyczna zrealizowanego rozwiązania jest prawem i przywilejem każdego odbiorcy tego obiektu lecz nie stanowi ona przeszkody w uznaniu go za przejaw tożsamości miejsca.

\section{Piśmiennictwo}

[1] Chorowska M., 2003: Rezydencje średniowieczne na Śląsku. Zamki, pałace, wieże mieszkalne, Wrocław.

[2] Dolczewski Z., 1996: Zamek książęcy czy królewskie „palatium”? O siedzibie ostatnich Piastów wielkopolskich [w:] Kronika miasta Poznania, 1996/1, 83-93.

[3] Kajzer L., Sokołowski S., Solm J., 2001: Leksykon zamków w Polsce, (red. Kajzer L.) Warszawa.

[4] Linette E., 1981: Zamek w Poznaniu, Warszawa - Poznań., 85.

[5] Łęcki W., Dolczewski Z., Korolczak Z., Kondziela H., Nowak A. J., Grygorowicz A., 2004: Zamek Królewski w Poznaniu, działania na rzecz restytucji, Poznań.

[6] Łukaszewicz J., 1998: Obraz historyczno-statystyczny miasta Poznania w dawniejszych czasach, Poznań, t. II, 211.

[7] Szumigała, P., 2004: Praca konkursowa "R" nr 115421 [w:] Zamek Królewski w Poznaniu, działania na rzecz restytucji, Poznań. 